\title{
FLORA DA SERRA DO CIPÓ, MINAS GERAIS: BOMBACOIDEAE (MALVACEAE)
}

\author{
VANIA NOBUKO YOSHIKAWA*, GERLENI LOPES ESTEVES** \& \\ MARÍLIA CRISTINA DUARTE* \\ * Laboratório de Sistemática Vegetal, Núcleo de Ciências Ambientais, Universidade de Mogi das \\ Cruzes, Avenida Candido Xavier de Almeida e Souza, Centro Cívico, 200, \\ 08780-911 - Mogi das Cruzes, SP, Brasil. Autor para correspondência: vania_nobuko@hotmail.com. \\ ** Núcleo de Pesquisa Curadoria do Herbário, Instituto de Botânica, \\ Av. Miguel Estéfano 3687, 04301-902 - São Paulo, SP, Brasil.
}

\begin{abstract}
Flora of the Serra do Cipó, Minas Gerais: Bombacoideae - Malvaceae). This study is part of the Project "Flora of the Serra do Cipó, Minas Gerais, Brazil". Bombacoideae is one of nine subfamilies of Malvaceae sensu lato, characterized by a nectariferous tissue situated inside on the base of the calyx, on petals or on the androgynophore. Trees with compound leaves characterize the subfamily. Three genera (Ceiba, Eriotheca and Pseudobombax) and eight species (C. pubiflora, C. speciosa, E. candolleana, E. macrophylla, E. pubescens, $P$. campestre, $P$. longiflorum and $P$. majus) were found in the studied area. They differ by floral characters such as number of free or united stamens in the staminal tube and by articulate or inarticulate leaflets. Eriotheca and Pseudobombax were the most representatives. Keys to identify genera and species, detailed descriptions, illustrations, taxonomic comments and a list of examined specimens are provided.
\end{abstract}

Key words: Bombacaceae, floristic, taxonomy.

Resumo - (Flora da Serra do Cipó, Minas Gerais: Bombacoideae - Malvaceae). O presente estudo compõe parte do projeto da Flora da Serra do Cipó, Minas Gerais, Brasil. Atualmente, Bombacoideae é uma das nove subfamílias de Malvaceae sensu lato, cuja sinapomorfia é a presença de um tecido nectarífero situado internamente na base do cálice, nas pétalas ou até mesmo no androginóforo. A subfamília apresenta indivíduos em sua maioria arbóreos e é caracterizada pela presença de folhas compostas. $\mathrm{Na}$ área de estudo foram encontrados três gêneros (Ceiba, Eriotheca e Pseudobombax) e oito espécies (C. pubiflora, C. speciosa, $E$. candolleana, E. macrophylla, E. pubescens, P. campestre, P. longiflorum e Pseudobombax majus), diferenciados principalmente por caracteres florais (número de estames e se totalmente concrescidos ou não no tubo estaminal, tamanho e cor das pétalas), e quanto à presença de folíolos articulados ou inarticulados, sendo o gênero Eriotheca o mais representativo. Chaves de identificação em nível genérico e específico, bem como descrições detalhadas, ilustrações, comentários taxonômicos e lista de materiais examinados são apresentados.

Palavras-chave: Bombacaceae, florística, taxonomia.

\section{MALVACEAE}

A família Malvaceae em sua atual circunscrição possui nove subfamílias: Malvoideae, Bombacoideae, Tilioideae,

Grewioideae, Helicterioideae, Sterculioideae, Byttnerioideae, Brownlowioideae e Dombeyoideae, apresentando como sinapomorfia, a presença de um tecido nectarífero constituído de tricomas glandulares situados internamente na base do cálice, nas pétalas ou no androginóforo (Alverson et al., 1999; Baum et al., 2004; Nyffeler et al,. 2005).

Esteves (1986) realizou o estudo taxonômico de Malvales na Serra do Cipó, considerando a circunscrição tradicional (Cronquist, 1981), onde foram encontradas 22 espécies distribuídas nas famílias Bombacaceae, Malvaceae, Sterculiaceae e Tiliaceae. Como resultados de seu trabalho, foram publicados os tratamentos de Bombacaceae e Tiliaceae sensu
Cronquist (1981), incluindo Apeiba tibourbou Aubl. e Triumfetta semitriloba Jacq. (Esteves, 1990) e Pseudobombax longiflorum (Esteves, 1992).

Malvaceae ainda não foi tratada na Serra do Cipó de acordo com a sua atual classificação (Alverson et al., 1999; Baum et al., 2004) e segundo Esteves (2014) seis subfamílias ocorrem na Serra do Cipó: Bombacoideae, Byttnerioideae, Grewioideae, Helicterioideae, Malvoideae e Sterculioideae.

Com isso, este trabalho teve como objetivo realizar o tratamento taxonômico das espécies da subfamília Bombacoideae (sensu Baum et al., 2004) ocorrentes na Serra do Cipó, uma vez que a publicação de Esteves (1992) foi feita há quase 30 anos e novos registros podem ter sido encontrados a partir de novas coletas realizadas.

Uma descrição de Malvaceae está apresentada em outro artigo desta série de flora (ColliSilva et al., 2019).

\footnotetext{
${ }^{1}$ Trabalho elaborado segundo o planejamento apresentado por Giulietti et al.(1987). Este trabalho faz parte da dissertação de mestrado da primeira autora
} 


\section{Bombacoideae Burnett.}

Árvores 3-30 m alt.. Tronco ventricoso ou retilíneo, aculeado ou inerme. Estípulas deltoides, caducas. Folhas 3-9-folioladas; folíolos obovados, geralmente discolores, raramente concolores, margem geralmente inteira, levemente repanda ou serreada, nervação reticulódroma. Cimas 1-10(-30) flores, 2,5-30 cm; pedicelo com brácteas 1-3, deltoides; cálice campanulado, subtubular a tubular; pétalas 5 , lineares, obovadas ou lineares, inteiras, geralmente indumentadas; tubo estaminal constrito ou retilíneo; filetes 5-300, livres. Cápsulas obovoides, elípticas, lineares ou oblongas; paina geralmente abundante, raramente escassa, alva, castanha ou parda, brilhante ou opaca. Semente castanho-clara ou castanhoescura, globosa, ovoide ou elipsoide, geralmente glabra, estriada, maculada ou verrucosa.

Bombacoideae engloba 160 espécies dentro de 18 gêneros, sendo distribuídos principalmente na região neotropical do globo terrestre, ocorrendo também no Paleotrópico: no continente africano, há 18 espécies nativas pertencendo aos gêneros Adansonia L., Bombax L. (utilizada em ornamentação pública no Brasil, sendo uma espécie exótica) e Rhodognaphalon (Ulbr.) Roberty (Carvalho-Sobrinho et. al., 2016).

No Brasil ocorrem 12 gêneros e aproximadamente 80 espécies, distribuindo-se em todas as regiões, sendo as regiões Norte e Nordeste as mais representativas e com altas taxas de endemismo (Duarte, 2010; Flora do Brasil 2020 em construção, 2019).

Das contribuições filogenéticas mais recentes, destaca-se a de Carvalho-Sobrinho et al. (2016), no qual classificou Bombacoideae em três clados distintos: (1) "Clado de Semente Alada", abrigando os gêneros Bernoullia Oliv., Gyranthera Pittier e Huberodendron Ducke; (2) o "Clado de Endocarpo Esponjoso" (Adansonia L., Cavanillesia
Ruiz \& Pav., Aguiaria Ducke, Scleronema Benth. e Catostemma Benth.); (3) e o "Clado Kapok" (suas cápsulas possuem abertura loculicida e endocarpo modificado em tecido lanoso, sendo a maioria, espécies que ocorrem no Brasil). Este último abriga o clado "Bombax do Paleotrópico" (Bombax L. e Rhodognaphalon A. Robyns), o "Clado Pachira s.l. corroborando Duarte et al. (2011) com os gêneros Pachira Aubl. e Eriotheca Schott \& Endl. e o "Clado do Tronco Estriado (Spirotheca Ulbr., Neobuchia Urb., Ceiba Mill., Pochota Seem. e Pseudobombax Dugand).

Após a publicação de Esteves (1992) sobre o grupo na Serra do Cipó, reportando apenas uma espécie (Pseudobombax longiflorum (Mart \& Zucc.) A. Robyns (ainda tratado na família Bombacaceae, atual Bombacoideae), foram realizadas coletas adicionais na área de estudo e como resultado houve um aumento de sete espécies: Ceiba pubiflora (A.St.-Hil.) K. Schum., Eriotheca candolleana (K. Schum.) A. Robyns, Eriotheca macrophylla (K. Schum.) A. Robyns, Eriotheca pubescens (Mart. \& Zucc.) A. Robyns, Pseudobombax campestre (Mart.) A. Robyns, Pseudobombax grandiflorum (Cav.) A. Robyns e Quararibea turbinata (Sw.) Poir. (Esteves, 2014), sendo esta última espécie atualmente classificada na subfamília Malvoideae (sensu Baum et al., 2004), não utilizada nesta monografia.

Desta forma, seguindo a delimitação de Baum et al. (2004) e de Carvalho-Sobrinho et al., (2016) todas as espécies encontradas neste trabalho pertencem ao Clado Kapok.

Bibliografia básica - Schumann (1886), Dugand (1943), Cuatrecasas (1954), Robyns (1963), Alverson et al. (1999), Baum et al. (2004), Esteves (2005), Nyffeler et al. (2005), Du Bocage e Sales (2002), Gibbs e Semir (2003), Duarte (2006), Duarte (2010), Duarte et al. (2011), Carvalho-Sobrinho (2006), Carvalho-Sobrinho et al. (2016).

Chave para os gêneros de Bombacoideae ocorrentes na Serra do Cipó

1. Folíolos inarticulados; pétalas com dois tipos de tricomas na face dorsal (estrelado e tufoso); semente maculada. 3. Pseudobombax

1'. Folíolos articulados; pétalas com um tipo de tricoma na face dorsal (estrelado); semente verrucosa ou estriada.

2. Tronco aculeado; folíolos com margem serreada; filetes 5-10; sementes verrucosas

1. Ceiba

2 '. Tronco inerme; folíolos com margem inteira; filetes 100-300; sementes estriadas......

2. Eriotheca

\section{Ceiba Mill.}

Arvoretas ou árvores 2-30 m alt., caducifólias. Tronco ventricoso, aculeado. Folhas (3)5-7-folioladas; pecíolo com 2 nectários oval-lineares na base; folíolos articulados, oblanceolados, elípticos, estreito-elípticos ou raramente lineares, cartáceos ou coriáceos, discolores ou concolores, margem serreada, ápice acuminado, agudo, arredondado, atenuado, mucronado, base aguda, decorrente, truncada, arredondada, faces glabras, nervação reticulódroma.
Cimas 1-6(-16) flores, 2,5-20 cm; brácteas 1-3; botões piriformes, elipsoides, ovoides ou obovoides, nectários 1-3 no receptáculo ou ausentes, globosos ou elípticos; cálice campanulado, ápice truncado ou (2)3-5-lobado; pétalas 5, reflexas, obovadas ou oblongas, inteiras, alvas, cremes, róseas ou lilases, com estrias basais vináceas, recobertas por tricomas estrelados, velutinas, lanuginosas ou seríceas em ambas as faces, ápice obtuso, truncado ou arredondado, raramente retuso, base truncada; tubo estaminal retilíneo, presença de 10 apêndices 
Flora da Serra do Cipó, Minas Gerais: Bombacoideae - Malvaceae

estreito-elípticos; filetes 5-10, parcialmente concrescidos ou soldados no tubo estaminal; anteras amarelas, alaranjadas ou alvas, estilete geralmente alvo ou raramente róseo, mais delgado que os filetes; estigma capitado, róseo ou alvo; ovário ovoide. Cápsulas obovoides ou elípticas, castanho-claras, glabras; paina alva. Semente castanho-escura, verrucosa.

Chave para as espécies

1. Pétalas obovadas com margem inteira, 5 anteras não formando um anel.

1'. Pétalas oblanceoladas com margem crenada, 10 anteras soldadas no ápice do tubo estaminal, formando um anel.

1.1. C. pubiflora

1.2. C. speciosa

1.1. Ceiba pubiflora (A. St.-Hil) K. Schum. in Mart., FI. bras. 12(3): 213. 1886.

Fig. $1 \mathrm{~A}, \mathrm{~B}$

Árvores (1,5-7)10-30 m alt., caducifólias. Tronco 40-150 cm dap. Estípulas $5 \mathrm{~mm}$ compr., $2 \mathrm{~mm}$ larg. Folhas (3)5-7-folioladas; pecíolo 7-12,5 cm compr.,2 nectários oval-lineares acima do pulvino até 1/3 apical; peciólulo 5-10 mm compr.; folíolos 7-13,3 cm compr., 3-3,6 cm larg., oblanceolados ou estreitoelípticos, cartáceos, discolores, margem $1 / 2$ apical levemente serreada, base inteira, ápice atenuado ou raramente acuminado, base aguda, faces glabras. Cimas 1-5(16) flores, 7-12 cm; pedicelo 13-30 mm compr., brácteas 1-3, opostas, caducas; botões 10-20 mm compr., 9-11 mm larg., globosos, nectários 1-2 no receptáculo; cálice 12-20 mm compr., 11-20 mm larg., campanulado, ápice fendido ou 3-5-lobado, lobos arredondados; pétalas $5,6-8 \mathrm{~cm}$ compr., 1,2-3,6 cm larg., obovadas, raramente eretas, inteiras, ápice obtuso ou arredondado, raramente retuso, base truncada, róseas ou lilases, base alva, com estrias basais vináceas, geralmente velutinas em ambas as faces; tubo estaminal 9-10 $\mathrm{mm}$ compr., retilíneo, presença de 10 apêndices estreito-elípticos, róseos; filetes 5, 28-45 mm compr., parcialmente concrescidos no tubo estaminal; anteras 3-6 mm compr., amarelas, róseas ou alvas; estilete 3-6 cm compr., geralmente alvo a raramente róseo; estigma capitado, róseo ou alvo; ovário ca. $5 \mathrm{~mm}$, ovoide. Cápsulas elípticas; paina abundante, alva. Semente $0,5 \mathrm{~mm}$.

Espécie facilmente identificada pelas pétalas obovadas e pelos 5 estames parcialmente concrescidos no tubo estaminal. Morfologicamente semelhante a $C$. speciosa pela coloração das pétalas (róseas ou lilases) e pelos folíolos com margem serreada. Porém, $C$. pubiflora possui 5 estames e pétalas com margem inteira e ápice arredondado, enquanto que $C$. speciosa possui 10 estames e pétalas com margem crenada e ápice truncado. Ceiba pubiflora distribui-se pelos estados da Bahia, Distrito Federal, Espírito Santo, Goiás, Mato Grosso, Mato Grosso do Sul, Minas Gerais, Rio de Janeiro e São Paulo, nos biomas Caatinga, Cerrado e Mata Atlântica (Flora do Brasil 2020 em construção, 2018a).

Flores observadas de maio a agosto. Frutos observados em outubro.
Material examinado: Santana do Riacho, Morro do calcário, Serra do Cipó, 4.V.1986, K. Kubtzki \& J. Rohwer CFSC 9806 (SPF).

Material adicional examinado: Distrito Federal, Brasília, 20.VIII.1973, E.P. Heringer s.n. (PAMG 134). Goiás, Campinaçu, estrada da Fazenda Praia Grande, 10.X.1995, B.M.T. Walter et al. 2821 (UFG). Minas Gerais, Buritizeiro, estrada para São Romão, km 17, 10.VI.2010, A.C. Cervi et al. 9850 (MBM).

1.2. Ceiba speciosa (A.St.-Hil.) Ravenna, Onira 3(15): 46. 1998.

Fig. 1 C, D, E

Árvores 4-23 m alt., caducifólias. Tronco 40$153 \mathrm{~cm}$ dap., às vezes tortuoso. Folhas 5-7-folioladas; pecíolo 5,5-17 cm compr., 2 nectários oval-lineares acima do pulvino até $1 / 3$ apical; peciólulo $1-1,5 \mathrm{~cm}$ compr.; folíolos 8,5-12 cm compr., 3-4,5 cm larg., oblanceolados, elípticos ou estreito-elípticos, cartáceos, discolores ou concolores, margem completamente a $1 / 3$ apical fortemente serreado, ápice acuminado ou atenuado, base aguda. Cimas 13(-5) flores, 8-15 cm; pedicelo 1,2-4 cm compr.; brácteas 1-3; botões 12-16 mm compr., 9-12 mm larg.; nectários ausentes; cálice 15-25 mm compr., 18$23 \mathrm{~mm}$ larg., campanulado, ápice irregularmente fendido ou (2)3-4-lobado, lobos deltoides ou arredondados; pétalas 5, 8-10 cm compr.; 1,5-3,2 cm larg., oblanceoladas, margem crenada, ápice truncado ou raramente retuso, base truncada, róseas ou lilases, com estrias basais vináceas, seríceas em ambas as faces; tubo estaminal $2 \mathrm{~cm}, 5-6 \mathrm{~cm}$ livres, presença de 10 apêndices estrito-elípticos; filetes 10 , soldados no tubo estaminal; anteras 4-6 mm, amarelas ou alvas, rimosas, formando um anel no ápice do tubo estaminal; estilete geralmente alvo ou raramente róseo; estigma 1-lobado, capitado, róseo; ovário ca. 5 $\mathrm{mm}$, ovoide. Cápsulas elipsoides, esverdeadas, glabras; paina abundante, alva, brilhante. Semente 9 $\mathrm{mm}$.

Espécie similar à Ceiba pubiflora. As diferenças e semelhanças estão descritas nos comentários de C. pubiflora. Esta espécie é amplamente utilizada no país para fins ornamentais, porém, espontaneamente ocorre na Bahia, Espírito Santo, Mato Grosso, Mato Grosso do Sul, Minas 

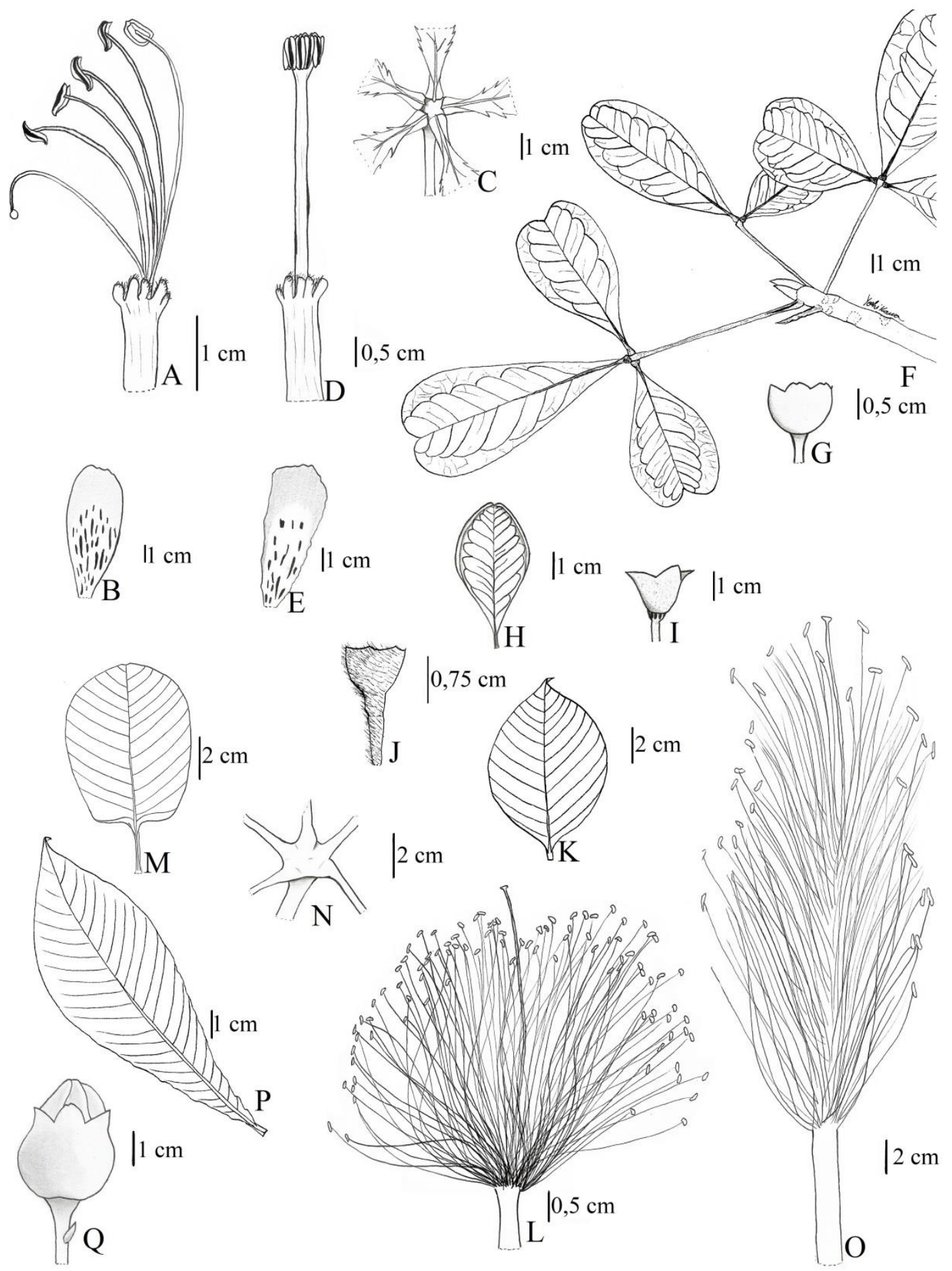

$2 \mathrm{~cm}$

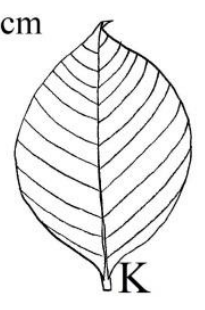

$2 \mathrm{~cm}$
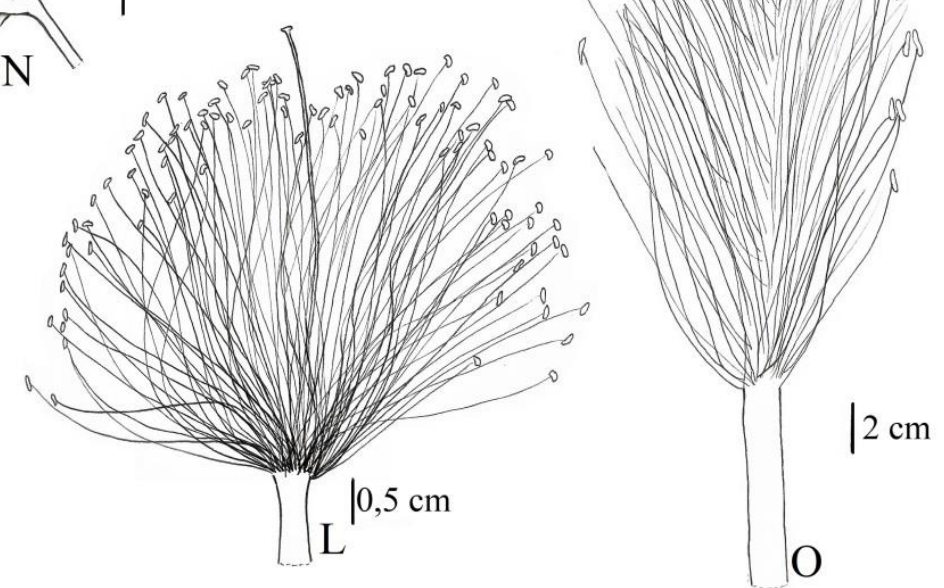

Fig. 1: A-B. Ceiba pubiflora. A. tubo estaminal; B. pétala vista ventral. C-E. Ceiba speciosa. C. inserção dos folíolos articulados. D. tubo estaminal. E. pétala vista ventral. F-G. Eriotheca macrophylla. F. ramo e folíolos. G. cálice. H-I. Eriotheca candolleana. H. folíolo. I. cálice. J. Eriotheca pubescens, cálice. K-L. Pseudobombax campestre. K. folíolo. L. tubo estaminal. M-O. Pseudobombax longiflorum. M. folíolo. N. dilatação do ápice do pecíolo (folíolos inarticulados). O. tubo estaminal. P-Q. Pseudobombax majus. P. folíolo. Q. botão floral. 
Flora da Serra do Cipó, Minas Gerais: Bombacoideae - Malvaceae

Gerais, Pará, Paraná, Santa Catarina, São Paulo e Rio Grande do Sul, nos biomas da Amazônia, Caatinga, Cerrado e Mata Atlântica (Flora do Brasil 2020 em construção, 2018a).

Flores observadas de abril a junho. Frutos observados em junho.

Material examinado: s.mun. Serra do Cipó, 5.IV.1958, F. Atala 185 (R); ibid. Fazenda São Vicente, 7.VI.1989, L.C. Bernacci s.n. (CEN 83722).

Material adicional examinado: São Paulo, Campinas, Fazenda Santa Elisa, 28.VI.2004, M.C. Duarte \& G.L. Esteves 26 (SP).

\section{Eriotheca Schott \& Endl.}

Arvoreta ou árvores, raramente arbustos $(0,7) 2-20 \mathrm{~m}$ alt., perenifólias. Tronco retilíneo ou tortuoso, inerme. Folhas 3-5 folioladas; peciólulo séssil; folíolos articulados, obovados, estreito ou largoobovados, cartáceos ou coriáceos, discolores ou concolores, margem inteira, ápice agudo, atenuado, cuspidado, frequentemente emarginado, retuso ou raramente mucronado, base aguda, decorrente, obtusa, truncada ou arredondada, face adaxial glabra ou lepidota, raramente com tricomas estrelados ou simples, face abaxial raramente glabra, geralmente lepidota ou com tricomas tectores, nervação reticulódroma. Cimas 1-10(-17) flores, 2-4 cm; brácteas 1-3; botões globosos, subglobosos, cilíndricos, ovoides ou obovoides, nectários globosos; cálice campanulado, ápice truncado, apiculado, crenulado, fendido, sinuoso ou lobado; pétalas 5, obovadas, reflexas ou eretas, inteiras, ápice obtuso ou arredondado, alvas, cremes, velutinas, recobertas por tricomas estrelados; tubo estaminal constrito ou raramente retilíneo; filetes 16-200; anteras amarelas; estilete geralmente alvo, mesma espessura dos filetes; estigma capitado; ovário ovoide ou piramidal. Cápsulas obovoides, castanhas claras, com escamas castanhas, ferrugíneas ou hialinas; paina, castanha ou parda. Semente globosa, castanho-escura, estriada.

Chave para as espécies

1. Ramos jovens e cálice recoberto por tricomas dourados ou hialinos

2.3. E. pubescens

1'. Ramos jovens e cálice recobertos por tricomas ferrugíneos.

2. Folíolos com margem revoluta; cálice recoberto por tricomas flocosos, presença de nectários negros

2' Folíolos com margem não-revoluta; cálice recoberto por tricomas estrelados; ausência de nectários no receptáculo.

2.1. E. candolleana 2.2. E. macrophylla

2.1. Eriotheca candolleana (K. Schum) A.Robyns, Bull. Jard. Bot. Etat 33 (1/2): 134. 1963

Fig. $1 \mathrm{H}, \mathrm{I}$

Árvores, 3-25(30) $\mathrm{m}$ alt. Tronco $15-125 \mathrm{~cm}$ dap., retilíneo. Estípulas 1-2 $\mathrm{mm}$ compr. Folha 5-9folioladas; pecíolo 3,5-8,5 cm compr., geralmente com 2 nectários oval-lineares até $1 / 3$ basal; peciólulo 1-5 mm compr.; folíolos 5,5-9 cm compr., 2-4,5 cm larg., obovados ou oblanceolados, cartáceos ou coriáceos, discolores, margem revoluta, ápice emarginado ou retuso, face adaxial glabra ou com escamas ferrugíneas, face abaxial com escamas mais abundantes que a face adaxial, ferrugíneas e/ou alvas, presença de nectário em $1 / 3$ apical da nervura primária da face abaxial. Cimas 1-6 flores, 3-4 cm; pedicelo 1-2,5 cm compr., brácteas 1-3, deltoides, ferrugíneas, no receptáculo; botões 6-9 cm compr., 4-7 cm larg., flocoso-ferrugíneos, nectários elípticos, formando um anel no receptáculo ou ausentes; cálice 0,4-1 cm compr., 0,8-1,1 cm larg., campanulado, ferrugíneo-flocoso, ápice 3-5-lobado, lobos deltoideagudos; pétalas $5,2,5 \mathrm{~cm}$ compr., $0,8 \mathrm{~cm}$ larg., obovadas, inteiras, 2/3 reflexas, ápice arredondado, alvas ou cremes, velutinas; tubo estaminal $0,5-1,3 \mathrm{~cm}$ compr.; filetes ca. 100-200, 1,5 cm; anteras $2 \mathrm{~mm}$, vináceas ou amarelas; estilete $1,5-2,5 \mathrm{~cm}$, estigma capitado. Cápsulas $6,3 \mathrm{~cm}$ compr., $3 \mathrm{~cm}$ larg., obovoide, castanho-claro, com escamas ferrugíneas; paina abundante, parda. Semente 4-5 mm, 2-estriada.

Eriotheca candolleana é facilmente distinta das demais pelo indumento flocoso-ferrugíneo que recobre o cálice e o pedicelo. A espécie é semelhante a $E$. macrophylla pelo indumento ferrugíneo, porém $E$. candolleana possui os ramos pardos, folíolos com margem revoluta e nervura primária proeminente em ambas as faces e paina mais abundante enquanto que E. macrophylla possui os ramos castanho-escuros, folíolos com margem não-revoluta e nervura primária proeminente apenas na face abaxial e paina menos abundante. Ocorre na Bahia, Distrito Federal, Espírito Santo, Goiás, Mato Grosso, Mato Grosso do Sul, Minas Gerais, Rio de Janeiro e São Paulo, nos biomas de Cerrado e Mata Atlântica (Flora do Brasil 2020 em construção, 2018b).

Flores observadas em fevereiro e em setembro. Frutos observados em novembro.

Material examinado: Santa Luzia, Gorduras de Cima, Serra do Cipó, 16.IX.1942, J. Nestor s.n. (BHCB 98404); Santana do Riacho, Serra do Cipó, 24.X.2008, M.F. Santos \& J.B.C. Marques 395 (SPF).

Material adicional examinado: Minas Gerais, Barroso, Mata do Baú, 14.II.2002, L.C.S. Assis 447 (RB); São Paulo, Limeira, 19.XI.1951, E. Kuhn 34 (HUMC, SP). 
2.2. Eriotheca macrophylla (K. Schum.) A.Robyns, Bull. Jard. Bot. Etat 33 (1/2): 152. 1963

Fig. $1 \mathrm{~F}, \mathrm{G}$

Árvores 8-10 m alt. Tronco retilíneo. Estípulas $5 \mathrm{~mm}$ compr., ferrugíneas. Folhas 3-5folioladas; pecíolo $5,5 \mathrm{~cm}$ compr., nectários 2 , ovallineares até $1 / 3$ basal; peciólulo nulo; folíolos $8 \mathrm{~cm}$ compr., $4 \mathrm{~cm}$ larg., obovados ou oblongos, coriáceos, discolores, face adaxial brilhante, opaca, ápice emarginado, base aguda, faces lepidotas de escamas ferrugíneas de contorno irregular, nervuras primárias e secundárias geralmente impressas na face adaxial e proeminentes na face abaxial, nectário não visto. Cimas 1-5(10) flores axilares e/ou apicais, 2-4 cm; pedicelo 1-3,5 cm compr., avermelhados ou verde-ferrugíneos, com cicatrizes de brácteas, brácteas 3, deltoides, no receptáculo; botões globosos, nectários ausentes; cálice $1 \mathrm{~cm}$ compr., 1,7 $\mathrm{cm}$ larg., campanulado, ápice crenulado ou 4-lobado, lobos arredondados, indumento ferrugíneo nãoflocoso; pétalas $5,2-3 \mathrm{~cm}$ compr., 0,5-1 cm larg., obovadas, geralmente reflexas, raramente eretas, margem inteira, ápice obtuso ou arredondado, cremes, geralmente velutinas; tubo estaminal $3-5 \mathrm{~mm}$ compr.; estames ca. 100, estilete ca. $1 \mathrm{~cm}$ compr., estigma capitado. Cápsulas $5-6 \mathrm{~cm}$ compr., $7 \mathrm{~cm}$ larg., obovoides, castanhas claras, com escamas não adpressas; paina menos abundante que nas demais espécies, castanha, brilhante ou opaca. Semente 0,5-1 cm.

Espécie facilmente reconhecida pelo indumento ferrugíneo não-flocoso e pelos folíolos opacos. Similar a E. candolleana pelo indumento ferrugíneo. Os comentários taxonômicos estão descritos em E. candolleana.

Eriotheca macrophylla ocorre em Alagoas, Bahia, Espírito Santo, Minas Gerais, Pernambuco e Rio de Janeiro, exclusivamente em Mata Atlântica (Flora do Brasil 2020 em construção, 2018b).

Flores observadas em março, agosto e setembro. Frutos observados em março, julho e dezembro.

Material examinado: Itambé do Mato Dentro, APA do Parque Nacional da Serra do Cipó, 15.III.2008, M.F. Santos \& H. Serafim 309 (SPF); ibid. 25.VIII.2007, M.F. Santos \& E.G. Martins 166 (BHCB).

Material adicional examinado: Minas Gerais, Carandaí, Fazenda Pedra do Sino, BR 040, km 512, trilha do Sauá, 22.IX.2007, N.F.O. Mota et al. 906 (BHCB); Cristália, mata ciliar do córrego Matão, 28.XI.1991, M.G. Carvalho \& S.T. Silva 801 (BHCB); s. mun. Serra da Piedade, mata de base, 13.VII.2001, X. André \& Rosane 64 (PAMG).

2.3. Eriotheca pubescens (Mart. \& Zucc.) Schott \& Endl., Melet. Bot. p. 35. 1832.

Fig. $1 \mathrm{~J}$

Árvores, raramente arbustos 2-10(-12) m alt.. Tronco $10-80 \mathrm{~cm}$ dap., tortuoso. Estípulas $3 \mathrm{~mm}$ compr. Folhas 3-5-folioladas; pecíolo 0,4-9,5(12) compr.; peciólulo 1-4 mm compr., a nulo; folíolos 6,5$15 \mathrm{~cm}$ compr., 1,4-6,5 cm larg., obovados, estreito ou largo-obovados, coriáceos, discolores, ápice emarginado, retuso ou arredondado, base aguda, decorrente ou cuneada, face adaxial glabra ou pubescente, às vezes com tricomas negros ou hialinos mais concentrados nas nervuras, ou com escamas ferrugíneas, face abaxial idem adaxial, porém mais concentrados; presença de nectário na nervura primária da face abaxial em $2 / 3$ apicais. Cimas 1-9(-15) flores, 3-4(5) cm; pedicelo 0,6-3 cm compr., brácteas 1-3, deltoides, no receptáculo; botões 4-10 mm compr., 5-8 mm larg., globosos, nectários, 1 no receptáculo ou ausentes; cálice 5-10 mm compr., 9-12 mm larg., campanulado, ápice truncado, fendido ou 5-apiculado; pétalas $5,2,5-3 \mathrm{~cm}$ compr., $1-1,5 \mathrm{~cm}$ larg., obovadas, $1 / 2$ reflexas, margem inteira, ápice obtuso ou arredondado, alvas ou cremes; tubo estaminal $2 \mathrm{~cm}$ compr.; filetes, ca. 200, 1-2 cm compr.; anteras 1-2 mm compr., amarelas; estilete $2 \mathrm{~cm}$ compr., geralmente alvo; estigma capitado. Cápsulas $4 \mathrm{~cm}$ compr., $4 \mathrm{~cm}$ larg., obovoides, com escamas ferrugíneas, pubescente; paina castanha ou parda. Semente 6-8,5 cm, castanho-escura, 4-estriada.

Eriotheca pubescens é a única espécie do gênero na Serra do Cipó que apresenta o cálice e o pedicelo recobertos por indumento tomentoso constituído de tricomas dourados. Similar a $E$. estevesiae Carv.-Sobr., ocorrente no estado do Tocantins pelo indumento pubescente presente nos ramos jovens, folhas, cálice e folíolos opacos. Eriotheca pubescens possui Iramos robustos (10-20 $\mathrm{mm}$ diam.), indumento dourado, folíolos predominantemente obovados, extremamente coriáceos e nectários ao redor do receptáculo, enquanto que $E$. estevesiae possui ramos mais delgados (4-8 $\mathrm{mm}$ diam.), tricomas amarelados, folíolos predominantemente lineares, cartáceos ou coriáceos e ausência de nectários no receptáculo. Eriotheca pubescens ocorre nos estados do Distrito Federal, Goiás, Mato Grosso, Mato Grosso do Sul, Minas Gerais e São Paulo, exclusivamente no Cerrado (Flora do Brasil 2020 em construção, 2018b).

Flores observadas de março a julho. Frutos observados em outubro.

Material examinado: Santana do Pirapama, Serra do Cipó, Fazenda Toucan Cipó, 13.III.2009, W. Milliken \& S.L. Edwards 4094 (SPF); ibid., Fazenda Inhame, 29.VII.2009, D.C. Zappi \& N.P. Taylor 2273 (SPF); Santana do Riacho, ao longo da Rodovia Belo Horizonte - Conceição do Mato Dentro, Serra do Cipó, 7.VI.1980, N.L. Menezes et al. CFSC 6186 (SPF); s.mun., Serra do Cipó, 20.IX.2011, C.M. Rodrigues 79 (HUFU, HUMC).

Material adicional analisado: Minas Gerais, Formoso, Fazenda Matinha, 10.X.1988, D. Alvarenga 115 (IBGE, UEC); Três Marias, 23.X.1969, E.P. Heringer 11901 (UB). 
Flora da Serra do Cipó, Minas Gerais: Bombacoideae - Malvaceae

\section{Pseudobombax Dugand}

Arvoreta ou árvores 1-18 m alt., caducifólias. Tronco levemente ventricoso ou retilíneo, inerme. Estípulas deltoides. Folhas 3-9(-11)-folioladas; pecíolo com ápice dilatado, com 2 nectários oval-lineares; peciólulo nulo ou presente, quando presente, canaliculado; folíolos inarticulados, soldados na dilatação do pecíolo, obovados, estreito ou largoobovados, oblongos, largo-elípticos, elípticos ou estreito-elípticos, cartáceos ou coriáceos, discolores ou concolores, margem inteira, ápice agudo, cuneado, arredondado, cuspidado ou retuso, base aguda, arredondada, cuneada, decorrente, truncada, faces glabras, com tricomas estrelados ou com escamas. Cimas 1-3(-6) flores, 6-20-(26) cm; pedicelo cilíndrico, brácteas 1-3, deltoides; nectários formando um anel no receptáculo em 1 eixo ou em 2 eixos; cálice campanulado, subtubular, tubular ou urceolado, ápice truncado, apiculado ou lobado; pétalas 5, lineares ou oval-lineares, reflexas ou eretas, margem inteira, ápice obtuso ou arredondado, alvas, cremes, esverdeadas, castanhas ou negras, escabras ou seríceas, tricomas estrelados e tufosos na mesma face; tubo estaminal retilíneo; filetes 100-300, livres ou em falanges, concrescidos na mesma ou em diferentes alturas; anteras amarelas; estilete alvo, mais espesso que os filetes; estigma capitado ou truncado; ovário ovoide ou piramidal. Cápsulas obovoides, lineares ou oblongas, castanho-claras, anguladas a não-anguladas, glabras ou tomentosas; paina castanha ou parda. Semente, ovoide ou elipsoide, maculada.

Chave para as espécies

1. Peciólulos 2-13 cm compr.; pétalas $14-23 \mathrm{~cm}$ compr., contorcidas, filetes concrescidos em diferentes alturas

no tubo estaminal ................................................................................................................. P. longiflorum

1'. Peciólulos até 1,2 cm compr.; pétalas 9-13 cm compr., não contorcidas, filetes concrescidos na

mesma altura no tubo estaminal

2. Folíolos largo-obovados, elípticos ou largo-elípticos; cálice campanulado com ápice truncado; estames ca.

100; cápsulas não anguladas ................................................................................................ 3.1. P. campestre

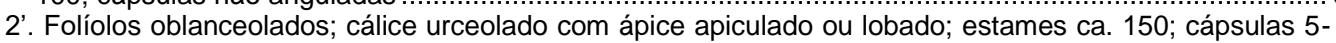

anguladas.

3.3. P. majus

3.1. Pseudobombax campestre (Mart.) A.Robyns, Bull. Jard. Bot. Etat 33: 65. 1963.

Fig. $1 \mathrm{~K}, \mathrm{~L}$

Árvores, 2-4(7) $\mathrm{m}$ alt. Tronco $35 \mathrm{~cm}$ dap., retilíneo, às vezes tortuoso. Folhas 3-5-folioladas; pecíolo 4-10 cm compr., glauco; peciólulo nulo ou 2 $\mathrm{mm}$ compr.; folíolos 10-29,5 cm compr., $8,5-12 \mathrm{~cm}$ larg., largo-obovados, elípticos ou largo-elípticos, cartáceos, discolores, margem inteira, ápice cuspidado, raramente arredondado, obtuso ou atenuado, base obtusa ou arredondada, faces glabras. Cimas 1-2 flores, 10-18(-22) cm; pedicelo 1-3,5 cm compr., brácteas 1-3; botões $10 \mathrm{~mm}$ compr., $10 \mathrm{~mm}$ larg.; nectários 10-15, elípticos, vináceos, geralmente formando anel em 1 eixo no receptáculo; cálice 8-12 $\mathrm{mm}$ compr., $12-17 \mathrm{~mm}$ larg., campanulado, ápice truncado, glabro; pétalas 5, 9-13 cm compr., $1-1,5 \mathrm{~cm}$ larg., lineares, reflexas, não contorcidas, margem inteira, ápice arredondado, externamente negras, castanhas, purpúreas ou vináceas, internamente alvas, cremes, ou esverdeadas; tubo estaminal 1-1,5 $\mathrm{cm}$ compr.; filetes ca. $100,6-9,5 \mathrm{~cm}$ compr., concrescidos na mesma altura; anteras $2 \mathrm{~mm}$ compr., amarelas; estilete 7-12 cm compr., alvo ou róseo; estigma capitado ou truncado, alvo ou vináceo; ovário piramidal. Cápsulas 5,5-14 cm compr., 1,6-3 cm larg., fusiformes ou turbinadas, não anguladas, castanhoescuras, ápice apiculado, com tricomas simples esparsos e glandulares abundantes; paina castanha ou parda. Semente 4-6 mm compr., $8 \mathrm{~mm}$ larg., castanha clara.

Espécie facilmente distinta das demais encontradas na Serra do Cipó pelos folíolos largo- obovados e estames em menor número entre as espécies da área de estudos. Assemelha-se a $P$. majus pelas pétalas não contorcidas, porém, $P$. campestre possui poucos folíolos (3-5), ca. 100 estames e pétalas mais estreitas $(1-1,5 \mathrm{~cm}$ larg.), enquanto que $P$. majus possui mais folíolos (5-12), ca. 150 estames e pétalas mais largas $(2-2,5 \mathrm{~cm}$ larg.).

Pseudobombax campestre ocorre exclusivamente no Cerrado, em Minas Gerais e na Bahia (Flora do Brasil 2020 em construção, 2018c).

Flores observadas de abril a julho e em dezembro. Frutos observados em julho.

Material examinado: Conceição do Mato Dentro, Rodovia Belo Horizonte - Conceição do Mato Dentro, Serra do Cipó, 20.VII.1987, R. Mello-Silva et al. CFSC 10255 (HUEFS, SPF); ibid., Rio Santo Antônio, 27.IV.1978, G. Martinelli 4413 (RB); Santana do Pirapama, Serra do Cipó, 13.XI.2009, D.C. Zappi 2371 (SPF); ibid., Fazenda Inhame, estrada velha para a mina de manganês, Serra do Cipó, 13.XI.2009, D.C. Zappi et al. 2371 (SPF); Santana do Riacho, Cardeal Mota, Morro da Pedreira, Serra do Cipó, 22.VII.1993, J.R. Pirani et al. CFSC 13260 (SPF); ibid., Serra do Cipó, 2.IV.1996, J.R. Pirani et al. 3687 (SPF).

3.2. Pseudobombax longiflorum (Mart. \& Zucc.) A.Robyns, Bull. Jard. Bot. Etat 33(1): 57. 1963. Iconografia em Esteves, 1992.

Fig. $1 \mathrm{M}, \mathrm{N}, \mathrm{O}$

Arvoreta ou árvore, 1-10(12) m alt. Tronco 6,8-20(-50) cm dap., retilíneo. Estípulas 6-7 mm compr. Folhas (4)-5-8(-9)-folioladas; pecíolo 11-40 cm compr.; peciólulo 2-13 cm compr.; folíolos $9-21 \mathrm{~cm}$ 
compr., 7,5-12 cm larg., oblongos ou elípticos, cartáceos ou coriáceos, discolores, ápice geralmente arredondado ou cuspidado, raramente cuspidadoretuso, base obtusa ou truncada, face adaxial glabra ou com tricomas simples diminutos hialinos e escamas negras arredondadas, face abaxial com escamas hialinas, nectário na nervura primária da face abaxial em 1/3 apical. Cimas 1-3 flores, $15-23 \mathrm{~cm}$; pedicelo 3$9 \mathrm{~cm}$ compr., brácteas (1)2-3; nectários 8-15, formando anel no receptáculo em 1 eixo; cálice 12-30 mm compr., 17-30 mm larg., subtubular ou tubular, ápice truncado, flocoso-ferrugíneo ou com escamas e tricomas simples; pétalas 5, 14-23 cm compr., 1,4-2 cm larg., lineares, reflexas, contorcidas, ápice obtuso, cuneado ou arredondado, externamente castanhas, negras, avermelhadas, esverdeadas, internamente alvas, amareladas ou rosadas; tubo estaminal $(2,5) 3-$ 6(-10) cm compr.; filetes ca. 150-200, 8-18 cm compr., concrescidos em diferentes graus no tubo estaminal; anteras 2-4 mm compr., amarelas; estilete 9,5-25 cm compr., alvo; estigma capitado; ovário $11 \mathrm{~mm}$. Cápsulas 16-27 cm compr., 5-5,5 cm larg., lineares, não anguladas, castanho-claras, glabras, ápice apiculado; paina castanha ou parda. Semente 4-5 mm.

Espécie facilmente reconhecida pelos peciólulos longos, pétalas contorcidas e frutos com ápice apiculado. Similar a Pseudobombax pulchellum Carv.-Sobr. pelos peciólulos igual ou maiores que 2 $\mathrm{cm}$, porém Pseudobombax longiflorum possui folíolos com ápice arredondado, cuspidado ou raramente cuspidado-retuso e base obtusa ou truncada, pétalas contorcidas e tubo estaminal de 2,5-10 cm compr., enquanto que $P$. pulchellum possui folíolos com ápice retuso, base arredondada, pétalas não contorcidas e tubo estaminal menor que $1 \mathrm{~cm}$ compr.

Pseudobombax longiflorum ocorre no Amazonas, Bahia, Distrito Federal, Espírito Santo, Goiás, Maranhão, Mato Grosso, Mato Grosso do Sul, Minas Gerais, Pará, Paraná, Piauí, Rio de Janeiro, Rondônia, São Paulo e Tocantins, em todos os biomas, exceto nos Pampas (Flora do Brasil 2020 em construção, 2018c).

Flores observadas de julho a setembro. Frutos observados de julho a setembro.

Material examinado: Santana do Riacho, Serra do Cipó, 14.XI.1984, G.L. Esteves et al. CFCR 5929 (HUEFS, SPF); ibid., 16.VII.1983, G.L. Esteves et al. CFCR 9123 (SPF); ibid., 1.VII.1981, A.M. Giulietti et al. CFSC 7383 (SPF); ibid., 21.VII.1980, N.L. Menezes et al. CFSC 6318 (SP, SPF).

3.3. Pseudobombax majus (A.Robyns) Carv.Sobr., PhytoKeys 85: 28. 2017.

Fig. $1 \mathrm{P}, \mathrm{Q}$

Árvore 7(20) m alt. Tronco $50 \mathrm{~cm}$ dap, acinzentado, retilíneo. Estípulas caducas. Folhas 59(12)-folioladas; pecíolo $16-30 \mathrm{~cm}$ compr.; peciólulo ca. $1 \mathrm{~cm}$ compr., folíolos 9-20 cm compr., 4-8 cm larg., oblanceolados, cartáceos, discolores, ápice cuspidado, base aguda, faces glabras, nectário não visto. Cimas com 1 flor apical, 15,5 cm; pedicelo 4,5$7,7 \mathrm{~cm}$ compr.; brácteas 1-3; nectários 11, no receptáculo; cálice 25-35 mm compr., 20-30 mm larg., urceolado, ápice 5-apiculado ou 3-4-lobado, glabro; pétalas $5,10 \mathrm{~cm}$ compr., $2-2,5 \mathrm{~cm}$ larg., lineares, reflexas, não contorcidas, ápice arredondado, aspecto carnoso, externamente negras e purpúreas, internamente alvas; tubo estaminal 5-5,5 cm compr.; filetes ca. 150, 6,5-10 cm compr., concrescidos na mesma altura; anteras 1-4 mm compr., pardas; estilete não visto; ovário $10 \mathrm{~mm}$ compr., piramidal. Cápsulas ca. $20 \mathrm{~cm}$ compr., oblongas, não-anguladas; paina parda abundante. Semente não vista.

Espécie caracterizada pelo cálice urceolado 5-apiculado ou 3-4 lobado. Morfologicamente similar à Pseudobombax marginatum (A.St.-Hil., Juss. \& Cambess.) A. Robyns pelos folíolos oblanceolados com as faces discolores. Pseudobombax majus possui o cálice urceolado e maior (25-35 mm compr., 20-30 $\mathrm{mm}$ larg.) e tubo estaminal não concrescido em falanges, enquanto que $P$. marginatum possui cálice campanulado e frequentemente menor (cálice 11-30 $\mathrm{mm}$ compr., $14-27 \mathrm{~mm}$ larg.) e tubo estaminal concrescido em 5 falanges.

Esta espécie ocorre predominantemente na Mata Atlântica dos estados da Bahia, Espírito Santo, Minas Gerais, Paraná, Rio de Janeiro, Rio Grande do Sul, Santa Catarina e São Paulo (Flora do Brasil 2020 em construção, 2018d), ocorrendo de forma parapátrica à Pseudobombax grandiflorum, o qual ocorre apenas em áreas de restinga (CarvalhoSobrinho \& Dorr, 2017). Difere-se morfologicamente de Pseudobombax grandiflorum principalmente em relação ao fruto angulado $v s$. não angulado e número de flores por cimas, sendo apenas solitárias em $P$. majus e 3-7 flores em $P$. grandiflorum.

Flores observadas em maio e junho. Frutos observados em agosto.

Material examinado: Itambé do Mato Dentro, Distrito de Santana do Rio Preto, APA Serra do Cipó, 18.V.2007, M.F. Santos \& H. Serafim 439 (SPF).

Material adicional examinado: Minas Gerais, Descoberto, Reserva Biológica Represa do Grama, 15.VI.2002, R.C. Forzza et al. 2206 (SPF); Santos Dumont, estrada de barro do Rio Paraopebas, 5.III.1995, R. MelloSilva 1019 (SPF). Rio de Janeiro, Rio de Janeiro, Taquara, cultivada na praça Colibri, estrada do Mapuá, 13.VIII.2016, C.D.M. Ferreira 49 (RB).

\section{Agradecimentos}

Os autores agradecem à Universidade de Mogi das Cruzes (UMC) pelo auxílio durante o desenvolvimento deste trabalho, à Coordenação de Aperfeiçoamento Pessoal de Nível Superior (CAPES) pelo financiamento concedido para a primeira autora (CAPES - 1702566-2017/1) e aos curadores e 
Flora da Serra do Cipó, Minas Gerais: Bombacoideae - Malvaceae

técnicos dos herbários visitados pela hospitalidade e acompanhamento durante as visitas realizadas.

\section{Referências}

ALVERSON, W.S.; WHITLOCK, B.A.; NYFFELER, R.; BAYER, C. \& BAUM, D.A. 1999. Phylogeny of the core Malvales: evidence from ndhF sequence data. Amer. J. Bot. 86: $1474-1486$.

BAUM, D.A.; SMITH, S.D.; YEN, A.; ALVERSON, W.S. \& NYFFELER, R. 2004. Phylogenetic relationships of Malvatheca (Bombacoideae and Malvoideae; Malvaceae sensu lato) as inferred from Plastid DNA sequences. Amer. J. Bot. 91: 1863-1871.

CARVALHO-SOBRINHO, J.G., ALVERSON, W.S., ALCANTARA, S. QUEIROZ, L.P., MOTA, A.C. \& BAUM, D.A. 2016. Revisiting the phylogeny of Bombacoideae (Malvaceae): Novel relationships, morphologically cohesive clades, and a new tribal classification based on mutilocus phylogeny analyses. Mol. Phyl. Evol. 101: 56-74.

CARVALHO-SOBRINHO, J.G. \& DORR, L.J. 2017. A new combination and taxonomic notes in Pseudobombax Dugand (Malvaceae). Phytokeys 85: 27-30.

COLLI-SILVA, M., ESTEVES, G.L. \& DUARTE, M.C. 2019. Flora da Serra do Cipó, Minas Gerais: Byttnerioideae, Helicterioideae e Sterculioideae (Malvaceae). Bol. Bot. Univ. São Paulo 37: 00-00.

CRONQUIST, A. 1981. An integrated system of classification of flowering plants. Columbia University Press. New York.

CUATRECASAS, J. 1954. Novelties in the Bombacaceae. Phytologia 4: 465-480.

DU BOCAGE, A.L. \& SALES, M.F. 2002. A família Bombacaceae Kunth no estado de Pernambuco, Brasil. Acta Bot. Bras. 16: 123-139.

DUARTE, M.C. 2006. Diversidade de Bombacaceae Kunth no estado de São Paulo. Dissertação em Biodiversidade Vegetal e Meio Ambiente. Instituto de Botânica da Secretaria de Estado do Meio Ambiente. São Paulo.

DUARTE, M.C. 2010. Análise filogenética de Eriotheca Schott \& Endl. e gêneros afins (Bombacoideae, Malvaceae) e estudo taxonômico de Eriotheca no Brasil. Tese de Doutorado em Biodiversidade Vegetal e Meio Ambiente. Instituto de Botânica da Secretaria de Estado do Meio Ambiente. São Paulo.
DUARTE, M.C. ESTEVES, G.L.; SALATINO, M.L.F. WALSH, K.C. \& BAUM, D.A. 2011. Phylogenetic analyses of Eriotheca and related genera (Bombacoideae, Malvaceae). Syst. Bot. 36: 690701.

DUGAND, A. 1943. Revalidaction de Bombax ceiba L. como espécie típica del género Bombax L. y descripcion de Pseudobombax gen. nov. Caldasia 2: 47-68.

ESTEVES, G.L. 1986. A ordem Malvales na Serra do Cipó, Minas Gerais, Brasil. Dissertação de Mestrado em Botânica. Universidade de São Paulo. São Paulo.

ESTEVES, G.L. 1990. Flora da Serra do Cipó, Minas Gerais: Tiliaceae. Bol. Bot. Univ. São Paulo 12: 6166.

ESTEVES, G.L. 1992. Flora da Serra do Cipó, Minas Gerais: Bombacaceae. Bol. Bot. Univ. São Paulo 13: 161-164.

ESTEVES, G.L. 2005. Flora da Reserva Ducke, Amazonas, Brasil: Bombacaceae. Rodriguésia 56: 115-124.

ESTEVES, G.L. 2014. Malvaceae. In PIRANI, J.R.; SANO, P.T.; MELLO-SILVA, R.; MENEZES, N.L.; ZAPPI, D.C. \& JONO, V.Y. Flora da Serra do Cipó, Minas Gerais. 2015. Disponível em: <http://www.ib.usp.br/botanica/serradocipo/angiosp erma/127-malvaceae/1441-malvaceae.html>. Acesso em: 12 de Fevereiro de 2019.

FLORA DO BRASIL 2020 em construção. 2018a. Ceiba. Jardim Botânico do Rio de Janeiro. Disponível em: <http://floradobrasil.jbrj.gov.br/ reflora/floradobrasil/FB9036>. Acesso em: 06 de Agosto de 2018.

FLORA DO BRASIL 2020 em construção. 2018b. Eriotheca. Jardim Botânico do Rio de Janeiro. Disponível em: <http://floradobrasil.jbrj.gov.br/ reflora/floradobrasil/FB27557>. Acesso em: 06 de Agosto de 2018.

FLORA DO BRASIL 2020 em construção. 2018c. Pseudobombax. Jardim Botânico do Rio de Janeiro. Disponível em: <http://floradobrasil.jbrj.gov.br/reflora/floradobrasil/ FB25761>. Acesso em: 06 de Agosto de 2018.

FLORA DO BRASIL 2020 em construção. 2018d. Pseudobombax majus. Jardim Botânico do Rio de Janeiro. Disponível em: <http://floradobrasil.jbrj.gov.br/reflora/floradobrasil/ FB603933 . Acesso em: 30 de Outubro de 2018. 
FLORA DO BRASIL 2020 em construção. 2019. Malvaceae. Jardim Botânico do Rio de Janeiro. Disponível em: $<$ http://floradobrasil.jbrj.gov.br/reflora/floradobrasil/ FB156>. Acesso em: 31 Maio 2019.

GIBBS, P. \& SEMIR, J. 2003. A taxonomic revision of the genus Ceiba Mill. (Bombacaceae). Anal. Jard. Bot. Madrid 60: 259-300.

GIULIETTI, A.M.; MENEZES, N.L.; PIRANI, J.R.; MEGURO, M. \& WANDERLEY, M.G.L. 1987. Flora da Serra do Cipó, Minas Gerais: Caracterização e lista das espécies. Bol. Bot. Univ. São Paulo 9: 1151.
NYFFELER, R.; BAYER, C.; ALVERSON, W.S.; YEN, A.; WHITLOCK, B.A.; CHASE, M.W. \& BAUM, D.A. 2005. Phylogenetic analysis of the Malvadendrina clade (Malvaceae s.l.) based on plastid DNA sequences. Org. Div. Evol. 5: 109-123.

ROBYNS, A. 1963. Essai de Monographie du genre Bombax L. s.l. (Bombacaceae). Bull. Jard. Bot. l'État Bruxelles 33: 1-311.

SCHUMANN, K. 1886. Bombacaceae. In C.P.F. Martius \& A.W. Eichler (eds.) Flora brasiliensis. Frid. Fleischer. Lipsiae, Monachii, vol. 12, pars 3, p. 202-250, tab. 40-50. 